\title{
Die inleidings en opskrifte van die vyf Siriese Apokriewe Psalms
}

\author{
H.F. van Rooy \\ Departement Klassieke en Semitistiek \\ Potchefstroomse Universiteit vir CHO \\ POTCHEFSTROOM
}

\begin{abstract}
The introductions and headings of the five Syriac Apocryphal Psalms

The existence of the five Syriac Apocryphal Psalms has been known since the eighteenth century. Psalm 151 was included in the Septuagint, whereas Hebrew versions of Psalms 151, 154 and 155 are part of the Psalms Scroll found in Qumran Cave XI. This paper explores the relationship between the headings of these Psalms in different traditions. In the Syriac transmission manuscript $12 t 4$ is of special importance and has a large number of unique readings as well as a number of important marginal notes. There are a number of important differences in the headings of the different traditions. The heading of Psalm 151 in 1214 was influenced by Athanasius and is also related to the heading in the Septuagint. The heading of Psalm 151 in the other Syriac manuscripts is probably related to a heading in the lost Hehrew Vorlage. The headings of Psalms 152 and 153 are part of an attempt to link these Psalms more closely to Psalm 151 and the Peshitta of 1 Samuel 16 and 17. The relationship between the different headings of Psalms 154 and 155 in $12 t 4$ and the other manuscripts is not easily definable. They are, however, related to the East Syrian headings of canonical Psalms 85 and 86.
\end{abstract}

\section{Inleiding}

Kennis van die bestaan van apokriewe Psalms wat nie deel was van die Hebreeuse Psalmbundel nie, is so oud soos die vertaling van die Psalms in Grieks. Die Septuagint bevat Psalm 151, wat aan Dawid toegeskryf word en wat inhoudelik verband hou met Dawid se woorde aan Saul voor sy geveg met Goliat (1 Samuel 17:34-37). Psalm 151 was ook deel van die Itala, die ou Latynse vertaling wat die Vulgaat voorafgegaan het. Sedert die agtiende eeu was dit ook bekend dat hierdie Psalm en nog vier ander voorkom in Siries, die 
taal van die vroee Oosterse Kerke (vgl. Baars, 1972:ii). 'n Eerste uitgawe van die vyf Siriese Apokriewe Psalms, gebaseer op twee manuskripte wat die Psalms bevat, het in 1887 verskyn (Baars, 1972:ii). In 1930 het Martin Noth 'n volgende uitgawe die lig laat sien, met gebruikmaking van vyf manuskripte (Noth, 1930). Die teks van Baars het in 1972 verskyn in die reeks waarin 'n kritiese teks van die Peshitta van die Ou Testament, die Siriese vertaling van die Bybel, gepubliseer word. Hy het van tien manuskripte gebruik gemaak. Slegs een van die manuskripte, wat uit die twaalfde eeu dateer, is 'n Psalmmanuskrip. Een is 'n manuskrip van profetiese boeke van die $\mathrm{Ou}$ Testament, wat die vyf Apokriewe Psalms aan die einde het. Die ander agt manuskripte is van 'n werk van die Siriese kerkvader, Elias van al-Anbar, waarin die vyf Psalms ook voorkom. Die teks van hierdie vyf Psalms in die enkele Psalmmanuskrip (manuskrip $12 \mathrm{t} 4$ volgens die numering wat in die kritiese teksuitgawe gebruik word) verskil op heelwat plekke van die teks wat in die ander manuskripte voorkom. Hierdie manuskrip het die Psalms in die volgorde 151, 152, 153, 154 en 155, terwyl al die ander manuskripte 'n ander volgorde het, naamlik 151, 154, 155, 152 en 153.

Van die vyf Siriese Apokriewe Psalms word Hebreeuse weergawes van drie aangetref in $11 \mathrm{Qps}^{\mathrm{a}}$, 'n Psalmrol van Qumran, wat benewens kanonieke Psalms ook 'n hele aantal apokriewe Psalms bevat (vgl. Sanders, 1965). Net Psalm 151 het in die Hebreeus 'n opskrif, terwyl al vyf van opskrifte voorsien is in die Siriese tekste. Die opskrifte in die manuskrip 12 t4 verskil egter op etlike plekke van die opskrifte in die ander manuskripte. Die opskrifte van Psalm 154 en 155 stem ten dele ooreen met die opskrifte van die kanonieke Psalms 85 en 86 volgens die Nestoriaanse tradisie, wat totaal verskil van die opskrifte van die Masoretiese teks. Die manuskrip $12 t 4$ word ook gekenmerk deur 'n hele aantal korreksies en kantlynaantekeninge, wat dikwels ooreenstem met die lesings van die ander manuskripte waar die ander manuskripte van $12 t 4$ verskil. In hierdie artikel word die verskillende weergawes van die opskrifte in die Siriese Psalms bespreek en die betekenis daarvan vir die geskiedenis van die oorlewering van die Psalms in die Siriese tradisie aangetoon. Die opskrifte en inleidings word in 'n eie Afrikaanse vertaling weergegee. Vir 'n volledige vertaling van die Hebreeuse en Siriese weergawes van hierdie Psalms, vergelyk Charlesworth en Sanders (1985).

Oor die ontstaan en oorsprong van die vyf Siriese Apokriewe Psalms bestaan daar meningsverskil onder geleerdes. Ten opsigte van Psalm 151 word redelik algemeen aanvaar dat die Siriese Psalm van die weergawe in die Septuagint (LXX) afhanklik is, wat weer tenggevoer kan word na 'n Hebreeuse oorspronklike. Die Hebreeuse oorspronklike was óf twee Psalms soos Psalm $151 \mathrm{~A}$ en $151 \mathrm{~B}$ van 11QPs ${ }^{\mathrm{a}}$, of 'n kombinasie daarvan reeds in die Hebreeus. 
Psalm 154 en 155 word gewoonlik teruggevoer na Hebreeuse oorspronklikes wat redelik nou verwant moes gewees het aan die weergawes in $11 \mathrm{QPs}^{\mathrm{a}}$. Noth (1930) was van mening dat die ander vier Psalms ook soos Psalm 151 eers in Grieks en toe in Siries vertaal is. Hierdie standpunt word egter nie meer algemeen ondersteun nie. Sommige geleerdes meen dat ook Psalm 152 en 153 direk uit Hebreeus vertaal is, saam met 154 en 155 (vgl. Haran, 1988:171, voetnoot 1). Daar is egter ook navorsers wat oordeel dat Psalm 152 en 153 oorspronklike werke in Siries is (vgl. Van Rooy, 1994 en 1995). Wat die verhouding tussen die verskillende Siriese manuskripte betref, maak Van der Woude (1974:32) 'n stelling wat by talle geleerdes voorkom, naamlik dat die kantlynaantekeninge van $12 \mathrm{t} 4$ die variante van al die ander Siriese manuskripte van die vyf Apokriewe Psalms bied.

\section{Die opskrifte van die Siriese Kanonieke Psalms}

Vir die verstaan van die opskrifte van die Siriese Apokriewe Psalms moet die saak van die opskrifte van die Psalms in die Peshitta ook aandag kry. In die verskillende manuskripte of uitgawes van die Peshitta word die Psalms of sonder opskrifte aangetref, of met opskrifte wat heeltemal verskil van die opskrifte in die Masoretiese teks of die LXX. Die opskrifte gee, waar dit wel voorkom, korter of langer interpretasies van die inhoud van die Psalms (Bloemendaal, 1960:1). Bloemendaal gee in sy proefskrif 'n goeie oorsig oor die geskiedenis van die bestudering van die Psalmopskrifte in die Peshitta en wys daarop dat van die begin van die geskiedenis van die vertaling van die Psalms in Siries die Hebreeuse opskrifte nie deel van die vertaling was nie. Die opskrifte in verskillende Siriese tradisies verskil ook van mekaar. 'n OosSiriese en Wes-Siriese tradisie kan onderskei word, terwyl 'n vermenging van die twee tradisies ook voorkom. Bloemendaal (1960:2-3) onderskei in die manuskripte en uitgawes van die Peshitta vier groepe:

* Opskrifte volgens die Oos-Siriese tradisie. In die manuskripte van hierdie tradisie kom nie veel variasie in die opskrifte voor nie.

- Opskrifte afhanklik van die Codex Ambrosianus, wat die Wes-Siriese tradisie verteenwoordig en wat heeltemal verskil van die eerste groep.

- Die opskrifte in die uitgawes van die Peshitta van Gabriël Sionita, die poliglots en Samuel Lee. Hierdie opskrifte gee dikwels twee betekenisse van 'n Psalm, naamlik 'n historiese en 'n allegoriese betekenis. Die historiese deel van die opskrifte van Sionita is dikwels dieselfde as die opskrifte van die Codex Ambrosianus. Hierdie derde groep is dikwels verwant aan die tweede groep. 
* Opskrifte wat nie tot die drie groepe afsonderlik behoort nie, maar wat dikwels ' $n$ vermenging is van die Oos-Siriese en Wes-Siriese tradisie. Sommige manuskripte se opskrifte is ook uniek.

\section{Psalm 151 en die algemene inleidings}

Oor die algemeen het navorsers nie baie aandag aan die opskrifte van die Siriese Psalms gegee nie. Dit is reeds die geval in Noth (1930) se bespreking, wat maar enkele opmerkings oor die opskrifte het. In al die manuskripte wat die vyf Apokriewe Psalms bevat, word Psalm 151 voorafgegaan deur 'n algemene inleiding. Daar is ook sekere Siriese Psalmtekste wat Psalm 151 bevat, wat dan ook deur ' $n$ inleiding voorafgegaan word. Hierdie inleiding toon in sommige gevalle 'n ooreenkoms met die inleiding van Psalm 151 in die LXX. Hieronder volg ' $n$ vertaling van inleidings wat belangrik is vir die bespreking, asook vertalings van die opskrifte wat by Psalm 151 voorkom in die verskillende tradisies.

\section{Vertalings van verskillende inleidings by Psalm $151^{1}$}

- Die inleiding in 12t4: Die een honderd een en vyftigste. Dit kom nie in die Hebreeus voor nie. 'n Inleiding tot die Psalm uit die werk van Eusebius bestaan nie. En uit dié van Athanasius, wat die woorde van die roem in die Here uitspreek: 'Maar selfs toe jy die kleinste was, is jy uitverkies tot een of ander nut vir jou broers. Jy is nie oor hulle verhef nie. Maar sing wanneer jy die eer gee aan die Here wat jou uitverkies het.' Die salige heer Theodorus, die kommentator, het nie ' $n$ inleiding opgestel nie. In die Siriese kopieë is dit sy nommer.

- Die inleiding in die ander Siriese manuskripte: Weer: Vyf Psalms van Dawid wat nie geskryf is in die ry van die Psalms nie.

- Die inleiding in manuskrip 6h22, 'n Siriese weergawe van Athanasius se Psalmkommentaar, gevolg deur die teks van Psalm 151, maar sonder kommentaar: Die een honderd en vyftigste. Hierdie Psalm is deur Dawid self geskryf en is buite die getal.

Hierdie opskrif van $6 \mathrm{~h} 22$ is 'n tipiese voorbeeld van die opskrifte en inleidings wat voorkom in die Peshitta-Psalmmanuskripte wat Psalm 151 bevat. In die samestelling van die teks van Psalm 151 volgens die Peshitta-Psalmmanuskripte het Baars van 15 manuskripte gebruik gemaak, naamlik 10 Peshitta-manuskripte en vyf van die Syrohexaplar. In hierdie manuskripte kom

1 Die vertaling self word in gekursiveerde druk weergegee - HFvR. 
'n aantal variante op die teks van $6 \mathrm{~h} 22$ voor, waarvan sommige minder en sommige meer belangrik is. So laat $7 \mathrm{t} 3$ die getal $151 \mathrm{weg}$. Daar is ook heelwat van die manuskripte wat 'n byvoeging soos die volgende of iets soortgelyks aan die einde het: Hy word nie gevind in al die kopieë nie. Hierdie byvoeging kan vergelyk word met die slotopmerking in $12 \mathrm{t4}$.

\section{Verskillende opskrifte van Psalm 151}

- Die Septuagint se opskrif: Hierdie Psalm is 'n outograaf van Dawid, buite die getal, toe hy teen Goliat geveg het.

- Psalm 151 se opskrif in 12t4: Van Dawid, toe hy alleen met Goliat geveg het.

- Psalm 151 se opskrif in al die ander manuskripte: 'n Danklied van Dawid.

- Psalm 15I se opskrif in 6h22: Toe hy alleen met Goliat geveg het.

- Psalm 151 se opskrif in IIQPsa: Halleluja, van Dawid, die seun van Isai.

\section{Die slot na Psalm 155 in 12t4:}

Voltooi is met die hulp van ons Heer die Psalmboek van die geseënde Dawid, profeet en koning, saam met wf Psalms, wat nie van die getal is nie, Grieks of Hebreeus, maar, soos hulle sê, hulle word in Siries gevind en ons het hulle geskryf vir die een wat gevra het.

Noth (1930:22) meen dat die opskrif van die Siriese Psalm ten doel het om die gebeure van die Psalm aan spesifieke gebeure in die lewe van Dawid te verbind. Die Psalm self is reeds duidelik in Dawid se mond geplaas, selfs sonder die opskrif.

Haran (1988:171) is van mening dat die opskrif in die LXX impliseer dat hierdie Psalm tot die LXX bygevoeg is nadat die boek van die Psalms klaar vertaal is. Dit is dus een van die latere vrugte van die Bybelse literatuur waarvoor daar wel 'n plek in die Griekse kanon gevind is. Die besondere klem van die opskrif in die LXX is dat die Psalm 'n idiographus van Dawid is, waardeur die vertaler twyfel uit die weg wou ruim insake die outeurskap van die Psalms. Haran (1988:181) meen dat die Griekse vertaler die volgende Hebreeuse opskrif voor hom gehad het: לרור בהלחמו את גלית (Van Dawid, toe hy met Goliat geveg het). Wat die opskrif van Psalm 151 in 11QPs ${ }^{\mathrm{a}}$ betref, oordeel Haran (1988:181) dat die halleluja nie hier hoort nie en dat dit oorgedra is van die einde van 'n voorafgaande Psalm, soos byvoorbeeld 150. 
Die basiese opskrif in 11QPsa is dus eintlik net: Vir Dawid. Verder oordeel Haran (1988:181-182) dat die uitbreiding, die seun van Isai, moontlik een van die uitbreidings van die skrywers te Qumran is. Verder meen hy dat die kort titel, sonder die verwysing na Goliat, moontlik die oorspronklike titel kan wees, omdat daar geen titel in die Psalms in die Masoretiese teks is met 'n verwysing na Goliat nie. Sulke verwysings kom wel by die LXX voor: in Psalm 151 en ook in Psalm 143:1.

Wigtil (1983) bespreek die volgorde van die vertalings van Psalm 151 en gee in sy bespreking aandag aan die opskrifte van die Psalm in die verskillende vertalings. Wigtil (1983:403-404) wys daarop dat die Siriese tradisie nie eenstemmig is oor die teks van die opskrif nie. In die kanonieke Psalmbundel begin die opskrif met die getal 151, en dan volg 'n opskrif wat ooreenstem met die begin van die Griekse opskrif. Daarop volg 'n gedeelte oor Dawid en Goliat. Hy wys ook op die lang inleiding tot $12 t 4$ en op die verdere opskrif, wat ook na Dawid en Goliat verwys. Hy verwys egter nie na die opskrif by die ander Siriese manuskripte nie. Sy standpunt is dat die Siriese opskrif meer verwant is aan die Grieks as aan die Hebreeus en dat 'n mens dus sou moes veronderstel dat 'n soortgelyke opskrif in 'n verlore Hebreeuse weergawe van Psalm 151 sou moes wees as 'n mens die Siries direk afhanklik van die Hebreeus wou stel.

Strugnell (1966:258-259) aanvaar ook dat die Hebreeus ten grondslag van die die LXX lê en dat die LXX 151A en B gekombineer het (258-259). Hy (1966:266-267) wys daarop dat die titel van die LXX nie aan die Hebreeus verwant is nie en dat die halleluja van die Qumranteks van die einde van Psalm 150 kon gekom het. Strugwell (1966:258) haal woorde van Athanasius in sy brief aan Marcellinus aan, wat in die inleiding van $12 t 4$ aangehaal word. Dit is 'n belangrike aanhaling, juis omdat die woorde van Athanasius nie volledig in die inleiding in $12 t 4$ aangehaal word nie - 'n gegewe wat die inleiding moeiliker mak om te verstaan. Die woorde eindig in die aanhaling met 'n imperatief, wat eintlik gerig was tot die leser van die brief van Athanasius. In 'n gedeelte waar verskillende Psalms vir verskillende omstandighede aanbeveel word, word die leser aangespoor om in sekere omstandighede Psalm 151 te sing. Die Grieks kan soos volg vertaal word:

\section{'n Vertaling van Athanasius se aansporing om Psalm 151 te sing}

'As jy, terwyl jy klein is, verkies word tot een of ander leier van jou broers, word jy nie oor hulle verhef nie, maar sing, terwyl jy aan God die eer gee, Psalm 151, wat 'n eie een is van Dawid' ('n Vertaling van die Grieks.) 
In die aanhaling in die inleiding in 1214 word die gedeelte Psalm 151, wat 'n eie een is van Dawid, weggelaat, sodat 'n mens die aanhaling moeilik kan verstaan sonder om na die oorspronklike te verwys. Die oorspronklike aanhaling handel oor 'n aanbeveling aan Marcellinus om nederig te bly wanneer hy in 'n gesagsposisie gestel word. Die skrywer van die inleiding in 12 t4 moes dus kennis gedra het van hierdie brief van Athanasius (vgl. Patrologiae Graeca 27:37).

Skehan (1976:144-149) gee meer volledig aandag aan die opskrifte van die Siriese Psalms asook aan die inleiding tot Psalm 151 in $12 \mathrm{t} 4$. Die Siriese Psalmtekste wat die inleiding het, sluit direk by die LXX aan. Die onderskrif ná die vyf Psalms wys dat die afskrywer afhanklik was van 'n Siriese bron vir al vyf onderskrifte. Die opskrif van die ander manuskripte, wat met weer begin, toon duidelik aan dat die oorskrywer dié Psalms van die Kanonieke Psalms onderskei.

Philonenko (1959:36-37) wys op die probleem van die algemene inleiding. Hy het nie die inleiding van $12 \mathrm{t} 4$ tot sy beskikking gehad nie, maar net die een wat by die ander manuskripte voorkom. Dié inleiding skryf al die Psalms aan Dawid toe, maar twee van die Psalms se opskrifte is duidelik nie Dawidies nie (Psalm 154 en 155). Psalms 151-153 is weer duidehk verbind deur die opskrifte aan 1 Samuel 17:34-36. Philonenko $(1959: 37,43)$ oordeel dat Psalm 154 se opskrif duidelik sekondêr is en dat Psalm 155 se opskrif nie met die inhoud van die Psalm ooreenstem nie.

Skehan (1976:144-145) wys ook daarop dat die volgorde van die vyf Psalms in $12 t 4$ verskil van die ander tekste en dat daar in $12 t 4$ 'n duidelike band deur die oorskrywer gelê word tussen Psalm 151 en Psalms 152 en 153. Hy meen ook dat die byvoeging in $12 t 4$ se kantlyn na $1 \mathrm{c}$ ' $n$ aanduiding is van die poging om die Psalms nouer te verbind en dat dit 'n ontwikkeling in die Siriese oordrag van die Psalms verteenwoordig.

Wacholder (1988:57-60) stel in sy bespreking van die opskrif van Psalm 151 dat die Bybel twee beelde van Dawid skilder, naamlik die historiese Dawid van Samuel en die geïdealiseerde Dawid van Kronieke. In die psalmopskrifte is daar soms 'n band tussen die historiese en die geïdealiseerde Dawid, maar in die Psalms self is daar min gegewens wat met die historiese Dawid verbind kan word. In die titel van Psalm 151 by Qumran word Dawid die seun van Isai genoem. Psalm 151 A en B is besig met die probleem van die verhiouding tussen Dawid as die geīnspireerde psalmis en die historiese Dawid as herder en kryger in Saul se diens. Wacholder gee ook aandag aan die verskil tussen hierdie opskrif en die LXX, waar hy met Sanders saamstem dat dit daar veral gaan om die gesag van die Psalm aan te toon. By Qumran was daar dan nie 
twyfel oor die gesag van die Psalm nie, soos uit die opskrif blyk. Wacholder sê dat Sanders meen dat die Hebreeuse en Griekse opskrifte onafhanklik is, maar dink self dat dit nie so duidelik is nie. Hy meen dat die Griekse titel kon teruggaan na 'n Hebreeuse weergawe wat nou verlore is. Die kopieerder van $11 \mathrm{QPs}^{\mathrm{a}}$ kon dan die titel verander het om weg te kom van die polemiese aard van die Hebreeuse Vorlage van die Grieks se titel en deur die verandering wou hy dan twyfel wegneem. Hy meen dat die opskrif van die Hebreeuse Vorlage van die LXX die oudste moes gewees het.

Ook Sanders (1965:54) onderskryf die standpunt dat die Siriese Psalm 151 van die LXX afhanklik is. Hy noem die Psalm 'n poëtiese midrasj op 1 Samuel 16:1-13 (Sanders, 1965:56). Wat die opskrifte betref, stel Sanders (1965:58) dat die LXX en Vetus Latina glad nie met die opskrif van Qumran of die Siries vergelyk kan word nie. Hy wys daarop dat die drie belangrike elemente van die LXX by Qumran ontbreek. Hierdie drie elemente is naamlik die gedagte dat dit 'n idiographus van Dawid is, dat dit aan Goliat verbind is en dat dit nie 'n kanonieke Psalm is nie. In Sanders se samevatting (1965:63) stel hy dat die opskrif in die LXX laat is, en dat hoewel die Siriese opskrif nader aan dié van Qumran is, dit baie waarskynlik is dat die drie opskrifte onafhanklik van die Psalm en van mekaar is. Sanders het van die bestaan van $12 t 4$ geweet en maak opmerkings in dié verband, maar hy was duidelik nie bewus van die opskrif van $12 \mathrm{t} 4$ nie.

Die slotskrif aan die einde van die vyf Apokriewe Psalms in 1214 is belangrik omdat daaruit blyk dat die oorskrywer duidelik onderskei het tussen kanonieke en apokriewe Psalms. Hy maak hierdie onderskeid selfs ten opsigte van Psaln 151, wat wel in die LXX aangetref word. Hy ken die vyf Apokriewe Psalnıs duidelik as ' $n$ eenheid in Siries wat so aan hom oorgedra is en wat op versoek in die manuskrip ingesluit is. Al ken hy die vyf as 'n eenheid, onderskei hy wel Psalm 151 van die ander vier deur die aparte inleiding tot Psalm 151 en die nuwe inleiding voor Psalm 152.

Wat die inleiding tot die vyf Siriese Psalms betref, moet die verskil tussen 1214 en die ander Siriese manuskripte wat hierdie Psalms betref, duidelik in ag geneem word. Wat die nommers van die Psalms betref, word die nommers net in $12 t 4$ aangetref en nie by die ander manuskripte nie. Tog is die nommer 151 nie 'n uitvinding van die oorskrywer van $12 t 4$ nie, aangesien die nommer $\infty$ k in 6h22, die Siriese weergawe van die kommentaar van Athanasius voorkom, asook baie pertinent in die brief van Athanasius aan Marcellinus, waar die getal met die letters PNA' aangedui word. Die feit dat die woorde van Athanasius se brief deur 12t4 aangehaal word, maak die oorskrywer, wat die getal betref, direk of indirek van Athanasius afhanklik. Die afhankhkheid van die oorskrywer aan Athanasius blyk nog verder uit die opskrif van 12 t4 by Psalm 151, 
na die inleiding, waar na Athanasius verwys is. Die LXX noem die Psalm 'n

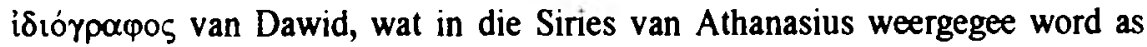
synde 'n Psalm wat deur Dawid geskryf is. Die verwysing dat die Psalm buite die getal is (dit wil sê, nie-kanoniek), kom nie in $12 t 4$ se inleiding voor nie, maar wel in die slotskrif wat na Psalm 155 aangetref word. Dit kan dus aanvaar word dat wat die nommer en die inleiding betref, die oorskrywer van $12 t 4$ van Athanasius afhanklik is. Ook die weergawe van die werkwoord in

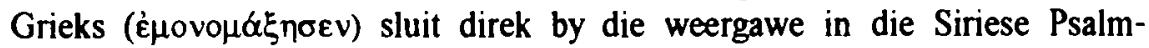
kommentaar van Athanasius aan. Sowel die opskrif as die slotskrif maak, weer in aansluiting by Athanasius, 'n duidelike onderskeid tussen die voorafgaande kanonieke Psalms en hierdie vyf Apokriewe Psalms. Die ander manuskripte wat deur Baars in sy kritiese teks gebruik is, het 'n ander inleiding as die een van 12t4. Hierin word die Psalms ook duidelik afgebaken van die inhoud van die res van die manuskripte.

Die verwysing na Goliat in die opskrif van $12 \mathrm{t} 4$ kom ook via Athanasius, wat weer van die LXX afhanklik is, alhoewel die plasing van Psalm 151 tussen die Apokriewe Psalms, teenoor die LXX, opgemerk moet word. Hierin volg 1214 ook vir Eusebius, Athanasius en Theodorus van Mopsuestia.

In Psalm 151 self word 'n lied aangetref wat aan Dawid toegeskryf word en waarin Dawid se uitverkiesing tot koning beklemtoon word en waarin teen die einde (moontlik in aansluiting by die beskadigde Psalm 151B van Qumran) Dawid se oorwinning oor Goliat verhaal word. Die opskrif in $12 t 4$ en die LXX sluit by hierdie laaste gedeelte van die Psalm aan. Die opskrif van Psalm 151 A in $11 Q^{2} s^{a}$ het nie die verwysing na Goliat nie, maar dit is nie vreemd nie, aangesien Psalm 151A self ook nie 'n verwysing na Goliat het nie. Die ander Siriese manuskripte se opskrif - 'n danklied van Dawid - verbind die Psalm wel aan Dawid, maar nie spesifiek aan die Goliat-episode nie. In dié opsig is daardie manuskripte nader aan Qumran, wat tog opmerklik is, omdat 1214 se teks gewoonlik nader aan Qumran is wanneer 12 t4 en die ander manuskripte van mekaar verskil. In elk geval kom daar in die Siriese manuskripte twee tradisies oor die opskrif voor, waarin 12 t4 deur Athanasius beinvloed is en die ander manuskripte se opskrif moontlik verband hou met 'n opskrif in 'n verlore Hebreeuse Vorlage wat verwant kon gewees het aan Psalm $151 \mathrm{~A}+\mathrm{B}$ van Qumran.

\section{Die opskrifte van Psalm 152 en 153}

- Die inleiding voor Psalm 152: Voor hierdie Psalm het 1214 weer 'n aparte inleiding, wat deels vir 152 geld en deels vir al vier die ander Psalms: Die een honderd twee en vyftigste. Daar bestaan nie inleidings deur Eusebius, 
Athanasius en die heer Theodorus, die kommentator, nie. Hierdie vier Psalms is egter hier opgeskryf.

- Die opskrif van Psalm 152 in 12t4: Gespreek deur Dawid toe hy met 'n leeu en 'n beer geveg het wat skape uit sy kudde weggedra het.

Die opskrif in die ander manuskripte vertoon enkele stilistiese afwykings in die Siries. Die enigste belangrike verskille is dat die opskrif na 'n skaap in die enkelvoud verwys en dat die getal 152 nie by die ander manuskripte voorkom nie.

- Die opskrif van Psalm 153 in 12t4: Die een honderd drie en vyftigste. Gespreek deur Dawid toe hy genade van God ontvang het, toe Hy hom verlos het van die leeu en die beer en hy hulle twee met sy hande gedood het.

Die opskrif in die ander manuskripte het weer net 'n aantal kleiner verskille. Die getal 153 kom nie by hulle voor nie, en ook nie die verwysing dat hy die diere "met sy hande" gedood het nie. Die ander verskille is bloot stilisties van aard en verander niks aan die inhoud van die opskrif nie.

Skehan (1976:147-149) gee uitvoerig aandag aan die opskrifte en inleidings van Psalms 151-153 aangesien hulle 'n belangrike rol in sy argumentasie speel. Hy vestig die aandag daarop dat Psalms 152 en 153 in Siries met 151 gekombineer is. Hiervoor is die opskrifte vir hom baie belangrik. Net $12 t 4$ het die nommers 151-155. Wat die ander volgorde by die ander manuskripte betref, oordeel Skehan dat Psalm 151, 152 en 153 by die ander manuskripte 'n raamwerk vorm wat die ander omraam en sodoende eintlik almal saam aan Dawid toegeskryf kan word. In $12 t 4$ is daar 'n bewuste poging om Psalms 151, 152 en 153 te verbind. Die opskrifte van Psalm 152 en 153 verbind die twee Psalms sterk aan die inhoud van Psalm 151 en die band word verder versterk deur die invoeging in die kantlyn van $12 \mathrm{t4}$ na Psalm $15 \mathrm{lc}$. Die werkwoord wat in die opskrif van Psalm 151 vir "veg" gebruik is ('tktš), kom ook in die opskrif van Psalm 152 voor, al is hierdie werkwoord nie baie geskik om die aksie van veg met diere uit te druk nie. Dit kom ook nie in die Psalm self voor nie - ook nie in Psalm 153 of in 1 Samuel 17:34-37 nie - 'n gegewe wat belangrik is vir die interpretasie van Psalm 152 en 153. Verder is dit ook so dat die bewoording van die opskrifte in 1214 Psalm 152 en 153 nouer verbind is aan die Peshitta van 1 Samuel as wat die geval is met die teks van die Psalms self. Skehan verwys byvoorbeeld na die werkwoord wat in die opskrif van Psalm 152 gebruik word vir die neem van die skape $(s q / w)$. Dieselfde werkwoord word ook in 1 Samuel 17:34 gebruik, terwyl in die Psalm self kmnw en tbrw gebruik word. Psalm 153 se opskrif eindig met "en die twee van hulle het hy met sy 
hande gedood", wat ooreenstem met 1 Samuel 17:36 in die Peshitta se "beide 'n leeu en ' $n$ wolf het $u$ dienskneg gedood".

Die aparte inleiding tot Psalms 152-155 in 1214 verdien beslis aandag. Die inleiding vestig die aandag weer daarop dat Athanasius, Eusebius en Theodorus nie inleidings tot hierdie Psalms geskryf het nie. Deur hierdie aparte inleiding word hierdie vier Psalms as apokrief aangedui, maar hulle word ook in $12 t 4$ as 'n aparte groep, los van Psalm 151, saam gebundel.

Wat die opskrif van Psalm 152 betref, kom daar wel (kleiner) verskille tussen $12 t 4$ en die ander manuskripte voor. Dit dui weer op die verskillende tradisies in die oorlewering van hierdie Psalms, alhoewel daar inhoudelik nie 'n wesenlike verskil tussen die twee tradisies is wat die opskrif van Psalm 152 betref nie. Die verskille is meer stilisties van aard (die byvoeging van $l h$ voor 'n eienaam met die voorsetsel $l$ vooraan en die byvoeging van $h w$ ' by twee deelwoorde).

Die aard van die verskille by die opskrif van Psalm 153 in $12 t 4$ en die ander manuskripte is van dieselfde aard as by Psalm 152 ('n Pael perfektum teenoor 'n deelwoord, tybwt' in die status determinatus in plaas van met 'n proleptiese voomaamwoordelike suffiks, $k d$ teenoor $d$ by die bysin en die weglating van $b^{\prime} y d w h y$ by die ander manuskripte).

Skehan is heeltemal korrek in sy siening dat die opskrifte van Psalms 152 en 153 die Psalms aan Psalm 151 verbind. Albei word aan Dawid toegeskryf en albei hou verband met gegewens in 1 Samuel. Verder moet opgemerk word, in ooreenstemming met Skehan, dat die opskrifte die twee Psalms nouer aan 1 Samuel in die Peshitta verbind as wat die geval is met die inhoud van die twee Psalms. Hierdie saak is elders volledig beredeneer (Van Rooy, 1994 en 1995). Psalm 152 is 'n klaaglied van Dawid, waarin hy om verlossing roep. Die opskrif dateer die Psalm egter nadat Dawid 'n leeu en 'n beer verslaan het wat skape uit sy vader se kudde wou roof. Die verwysing na die twee roofdiere is ook duideliker in die ander manuskripte as in 12t4. Psalm 153 is 'n danklied van Dawid, wat deur die opskrif ook verbind word aan Dawid se oorwinning oor die roofdiere. Hier is die verwantskap tussen die inhoud van die Psalm en die opskrif duideliker as in Psalm 152.

\section{Die opskrifte van Psalm 154 en 155}

- Die opskrif van Psalm 154 in 12t4: Die een honderd vier en wftigste. Die gebed van Hiskia toe die Assiriërs hom omsingel het en hy van God hevryding van hulle gevra het. Toe die volk toestemming van Cyrus ontvang het om na hulle land terug te keer en hulle God gevra het om hulle verwagting te vervul. 
- Die opskrif van Psalm 154 in die ander manuskripte: Gebed van Hiskia toe vyande hom omsingel het.

- Die opskrif van Psalm 155 in 12t4: Die een honderd vyf en vyftigste. Die gebed van Hiskia toe die Assiriërs hom omsingel het en hy van God verlossing van hulle gevra het.

- Die opskrif van Psalm 155 in die ander manuskripte: Toe die volk toestemming van Cyrus ontvang het om na hulle land terug te keer.

\section{Die opskrifte van Psalm 85 en 86 in die Oos-Siriese tradisie}

Vir die bespreking van die opskrifte van Psalm 154 en 155 is die opskrifte van Psalm 85 en 86 in die Oos-Siriese tradisie belangrik:

- Psalm 85: Toe die volk toestemming van Cyrus ontvang het om na hulle land terug te keer en hulle God gevra het om hulle verwagting te vervul.

- Psalm 86: Die gebed van Hiskia toe die Assiriërs hom omsingel het en hy verlossing van God van hulle gevra het.

Skehan (1976:156) stel dat die dubbele opskrif wat in 1214 voor Psalm 154 voorkom, aansluit by die bekende Oos-Siriese opskrifte vir Psalm 85 en 86. Dit is afgelei van die opskrifte of opsommings van Theodorus van Mopsuestia en het teen 600 n.C. in die Oos-Siriese weergawe van die Peshitta 'n vaste vorm in die kanonieke Psalms gekry. Hy meen egter dat die samesteller bedoel het om die Hiskia-gebed aan Psalm 155 te verbind en dat die tweede deel van Psalm 154 se opskrif dan by daardie Psalm hoort. Al die ander getuies het dit egter andersom as wat 'n mens sou verwag: hulle plaas die Hiskia-opskrif by Psalm 154 en die een wat na Kores verwys by Psaim 155.

Charlesworth en Sanders (1985:620) merk oor die opskrif van 12t4 by Psalm 154 op dat die opskrif baie laat is en dat dit geen verband het met die inhoud van die Psalm nie en hulle (1985:623) het dieselfde opmerking oor die opskrif van Psalm 155.

Wacholder (1988:68) gee ook aandag aan die moontlike verskille ten opsigte van Psalm 154 en 155 se opskrifte en aan die feit dat die twee Psalms by Qumran in 'n bundel opgeneem word wat aan Dawid toegeskryf word, terwyl Psalm 154 en 155 albei aan Hiskia toegeskryf word, volgens die opskrifte. Hy wys daarop dat Charlesworth hierdie latere omskrywings wil afwys en dat hy sê dat dit net in een manuskrip voorkom en dat dit baie laat is. Wacholder meen self dat dit onwaarskynlik is dat 'n latere redakteur sulke opskrifte op sy eie sou uitgedink het. Hy meen dus dat die Hebreeuse weergawes van die opskrifte moontlik deur 'n samesteller van die Qumranrol verander is. Hy 
meen dat dit dan daarop dui dat die Vorlage van die Siriese Psalms ouer moet wees as dié van die Qumran-tekste. Die probleem met sy siening is dat hy duidelik nie kennis geneem het van wat presies die stand van sake is met die opskrifte van die Psalms in Siries nie en sy konklusies is dus op 'n verkeerde aanname gebou.

Ten opsigte van Psalms 154 en 155 is daar drastiese verskille tussen die opskrifte in 12 t4 en die ander manuskripte. Soos Skehan aangedui het, hou die opskrifte verband met die Oos-Siriese opskrifte van Psalms 85 en 86, maar die wyse waarop die opskrifte hier aangewend word, wyk af van die opskrifte soos dit by Psalms 85 en 86 voorkom. Skehan het nie voldoende aandag gegee aan hierdie afwykings nie. Psalm 154 vertoon 'n gemengde vorm. Dit kan in die algemeen 'n wysheidslied genoem word (Sanders, 1965:68; Van der Woude, 1974:36). Psalm 155 is weer 'n individuele klaaghed verbind aan 'n danklied. Van der Woude plaas die klaaglied eerste en die danklied tweede (1974:36) en Sanders (1965:73) doen dit andersom. Indien die inhoud van die twee Psalms in gedagte gehou word, is Skehan se opmerking korrek dat 'n mens die opskrif van Psalm 85 by Psalm 154 sou verwag en Psalm 86 s'n by Psalm 155. Wat egter gebeur, is dat by Psalm 1541214 die twee opskrifte kombineer en dat die ander manuskripte 'n aangepaste vorm van die opskrif van Psalm 86 het. Psalm 86 se opskrif word in 1214 eerste gegee, opgevolg deur die opskrif van Psalm 85 . Wat die opskrif van Psalm 86 betref, het $12 t 4$ net een verskil met die teks soos by Bloemendaal, naamlik die byvoeging van $h w^{\prime}$ na die deelwoord $\xi^{\prime} l$. Hierdie variant kom glad nie voor in enige van die getuies wat deur Bloemendaal (1960:67) gebnik word nie. Verder kom daar enkele kleiner variante voor, naamlik die lesing ' $k m n$ in $12 t 4$ in plaas van ' $y k m n$ soos by Bloemendaal (1960:67) en $m n$ ' $l h$ ' in plaas van $l ' l h$ '. Bloemendaal (1960:67) gee wel een getuie wat ook ' $\mathrm{km} n$ lees, en ' $\mathrm{n}$ hele aantal wat $m n$ ' $/ \mathrm{h}$ ' het. By Psalm 155 het $12 t 4$ weer die opskrif van Psalm 86, maar sonder die byvoeging van $h w^{\prime}$ na die deelwoord $\xi^{\prime} l$, soos by Psalm 154 .

Die ander manuskripte sluit ook by die opskrifte van Psalms 85 en 86 aan. By Psalm 154 het hulle die Hiskia-opskrif, maar in 'n heel unieke vorm. Hulle het nie die ' $h u$ ' wat by $12 \mathrm{t} 4$ en in die opskrif van Psalm 86 voorkom nie. Hierdie ander manuskripte vervang 'twry' (Assiriërs) ook met $b^{c} l d b b^{\prime}$ (meervoud; vyande) - iets wat by geen van die getuies in Bloemendaal voorkom nie. Ook word die gedeelte van $s^{\prime} l$ (vra) tot aan die einde weggelaat. Bloemendaal het wel 'n hele aantal getuies wat die verwysing na die Assiriërs weglaat en twee wat ook die laaste gedeelte weglaat. By Psalm 155 het die ander manuskripte ook die laaste gedeelte van die inleiding van Psalm 85 weggelaat - van $\zeta^{\prime} l y n$ (vra) tot aan die einde. Ook hier het Bloemendaal (1960:67) 'n aantal getuies wat die weglating ondersteun. In albei gevalle is die lesing van die ander 
manuskripte baie naby aan Bloemendaal se manuskrip H, Mingana 428 van 1824. Die ander manuskripte het dus verkorte titels teenoor die gangbare OosSiriese tradisie en een heel unieke lesing met die verwysing na vyande in plaas van die Assiriërs in Psalm 154. Tog moet die tradisie van die titels in die ander manuskripte op een of ander wyse verband hou met die opskrifte soos in 12t4, juis omdat opskrifte van dieselfde twee Psalms gebruik word. Hoe die saak presies ontwikkel het, kan met die huidige inligting nie bepaal word nie. Dit is deels daaraan te wyte dat Theodorus se Psalmkommentaar net fragmentaries behoue gebly het en dat sy kommentaar op Psalms 85 en 86 deel is van dit wat verlore gegaan het. Dit is egter duidelik dat $12 \mathrm{t} 4$ en die ander manuskripte hier twee verskillende tradisies verteenwoordig, soos wat ook die geval is met die inhoud van die twee Psalms (vgl. Van Rooy, 1993a en 1993b). 'n Verdere bestudering van die oorspronklike Siriese manuskripte kan dalk meer lig op hierdie saak werp, juis omdat die opskrifte van die manuskrip 12 t4 nie deur Bloemendaal gepubliseer is nie.

\section{Konklusie}

Uit hierdie studie blyk sekere belangrike ooreenkomste en verskille in die Siriese opskrifte van Psalms 151-151. Die verskille is belangrik vir die beoordeling van die oorlewering van hierdie Psalms in Siries. By Psalm 151 is 12 t4 deur Athanasius beïnvloed en die ander Siriese manuskripte se opskrif hou moontlik verband met die verlore Hebreeuse Vorlage. Dit moet egter onthou word dat in die Siriese tradisie die opskrifte van die kanonieke Psalms nie deur die Peshitta oorgeneem is nie. By Psalms 152 en 153 is die opskrifte deel van 'n poging om die twee Psalms nouer aan Psalm 151 en die Peshitta van 1 Samuel 16 en 17 te verbind. Die presiese oorsaak van die verskille in die opskrifte van Psalms 154 en 155 is tans nog moeilik bepaalbaar. Dit hou egter nie verband met die Hebreeuse oorspronklike opskrifte nie, maar is verwant aan die opskrifte van Psalms 85 en 86 in die Oos-Siriese tradisie.

\section{Bibliografie}

BAARS, W. 1972. Apocryphal Psalms. (The Old Testament in Syriac, Part IV, fascicle 6.) Leiden : Brill.

BLOEMENDAAL, W. 1960. The headings of the Psalms in the East Syrian Church. Leiden : Brill.

CHARLESWORTH, J.H. \& SANDERS, J.A. 1985. More Psalms of David. (In Charlesworth, J.H. ed. The Old Testament epigrapha. Volume 2. Garden City, New York : Doubleday. p. 609-624.)

HARAN, M. 1988. The two text-forms of Psalm 151. Journal of Jewish Studies, 39:171-182. 
NOTH, M. 1930. Die füf syrisch überlieferten apokryphen Psalmen. Zeitschrift für die alttestamentliche Wissenschaft, 48:1-23.

PHILONENKO, M. 1959. L'origine essénienne des cinq Psaumes Syriaques de David. Semitica, 9:35-48.

SANDERS, J.A. 1965. The Psalms scroll of Qumrân cave $11\left(11 \mathrm{QPs}^{\mathrm{a}}\right)$. (Discoveries in the Judean Desert IV.) Oxford : Clarendon Press.

STRUGNELL, J. 1966. Notes on the text and transmission of the Apocryphal Psalms 151, 154 (= Syr. II) and 155 (=Syr III). Harvard Theological Journal, 59(3):257-281.

SKEHAN, P.W. 1976. Again the Syriac Apocryphal Psalms. Catholic Biblical Quarterly, 38(2):143-158.

VAN DER WOUDE, A.S. 1974. Die fünf syrischen Psalmen. (In Kümmel, W.G. Hrgb. Poetische Schriften. Jüdischen Schriften aus hellenistischrömischer Zeit. Band IV. Lieferung 1. Gutersloh : Verlagshaus Gerd Mohn. p. 31-47.)

VAN ROOY, H.F. 1993a. The Hebrew and Syriac version of Psalm 154. Journal for Semitics, 5:97-102.

VAN ROOY, H.F. 1993b. Psalm 155: one, two or three texts? Revue de Qumran, 58:149-162.

VAN ROOY, H.F. 1994. The origin of the Syriac Apocryphal Psalm 153. Journal for Semitics, 6(2): 192-200.

VAN ROOY, H.F. 1995. The textual traditions and origin of the Syriac apocryphal Psalm 152. Journal of Northwestsemitic Languages, 21(2):93104.

WACHOLDER, B.Z. 1988. David's eschatological Psalter 11QPsalms ${ }^{\mathrm{a}}$. Hebrew Union College Annual, 59:23-72.

WIGTIL, D.N. 1983. The sequence of the translations of Apocryphal Psalm 151. Revue de Qumran, 11(43):401-407. 
112 